\title{
Native shade trees aid bird conservation in tea plantations in southern India
}

\author{
T. R. Shankar Raman ${ }^{1, *}$, Chayant Gonsalves ${ }^{1,2}$, P. Jeganathan ${ }^{1}$ and \\ Divya Mudappa ${ }^{1}$ \\ ${ }^{1}$ Nature Conservation Foundation, 1311 'Amritha' 12th A Main, Vijayanagar 1st Stage, Mysuru 570 017, India \\ ${ }^{2}$ Present address: C-01, Good Earth Malhar Footprints, Kambipura Taluk, Kengeri Hobli, Bengaluru 560 074, India
}

In the Western Ghats, India, we study how different intensities of tea cultivation influence birds. We compared bird communities in conventional monoculture tea and mixed-shade tea plantations, both of which use agrochemicals, with organic tea plantations, a rainforest fragment, and continuous rainforest within the Anamalai Tiger Reserve. In 225 point count surveys, overall bird species richness and abundance were lowest in conventional tea and up to $33 \%$ higher in organic tea. Mixed-shade tea had $40 \%$ higher species richness (including 15 canopy and 4 shrub and mid-storey species - primarily frugivores, nectarivores and insectivores), and $83 \%$ higher bird abundance than conventional tea, with a greater proportion of forest-affiliated birds and similarity in species composition with forest sites. The rainforest fragment and continuous rainforest had a higher proportion, richness and abundance of forest-affiliated birds and fewer open-country birds, unlike tea plantations where the pattern was reversed. Habitat associations of 62 bird species in indicator species analysis revealed similar patterns. Thus organic tea is better than conventional tea for birds, but mixed-shade tea is even better, although still poorer than forests. Retaining or promoting native shade trees in tea plantations will increase bird diversity and abundance, including of forest-affiliated species and support landscape-level bird conservation.

Keywords: Bird community structure, indicator species, land-use change, shade trees, tea plantations.

ACROSS the tropics, intensification of land use for agriculture and monoculture plantations remains a conservation concern because of its effects on biological diversity. Conservation biologists have been interested in the conservation value of such plantations outside protected are$a^{1,2}$, particularly for taxa like rainforest birds that are dependent on diverse and structurally complex forest habitat $^{3-5}$. Forest remnants and plantation habitats influence each other based on their connectivity at the landscape level as well as their patch-level habitat characteristics. At the landscape level, rainforest bird

*For correspondence. (e-mail: trsr@ncf-india.org) diversity may increase in habitat fragments that adjoin shade-grown plantations with tree cover $^{6}$, while bird diversity in plantations may increase due to the presence of embedded or adjoining habitat fragments ${ }^{6,7}$ and due to extent of forest cover in the wider landscape ${ }^{8,9}$. At the habitat level, rainforest bird community composition may be altered due to changes in forest vegetation structure and tree species composition ${ }^{6,10-12}$. In human-altered habitats such as shade-grown plantations of coffee, cocoa and cardamom, bird diversity and community composition are known to be influenced by the extent of tree cover and diversity of native tree species used as shade within plantations ${ }^{3,4,6,13-16}$. The responses of birds to habitat alteration also differ in relation to their habitat affiliation with sites characterized by higher tree cover and density, especially of native tree species, supporting more forestaffiliated and fewer open-country bird species ${ }^{4,6,17,18}$.

The effects of habitat alteration may be especially significant in the case of intensive monocultures such as tea plantations. Tea is cultivated in over 6.5 million hectares globally and area under tea production continues to expand $^{19}$. In India, area under tea plantations has increased from 521,400 ha in 2003 to 636,600 ha in 2020 (refs 20, 21). Most tea plantations are located in regions of highbiodiversity tropical forests ${ }^{22}$, and tea is typically grown as open monocultures with sparse tree cover, often with a single tree species like silver oak Grevillea robusta as in southern India ${ }^{4}$. While tea plantations with more diverse shade tree cover are rare, some of them follow organic cultivation practices that may also influence bird communities. While many studies have established the generally positive effects of organic farming on biodiversity through increased species richness and abundance of plant and animal taxa in the developed countries in the temperate region ${ }^{23-26}$, limited information is available from tropical countries ${ }^{27}$, including from tea plantations. Studies on tea plantations are important from the perspective of the role of birds as bioindicators ${ }^{28}$ and their role in control of insect pests ${ }^{15}$, as bird diversity is often related to increased pest control ${ }^{29-32}$.

The limited research worldwide on the effects of tea plantations on bird communities has not addressed how variation in tea cultivation practices (conventional cultivation with agrochemical use versus organic cultivation) 
and the presence of native shade trees influence bird community structure. In the Anamalai Hills of the Western Ghats, India, the tea-growing landscape exists alongside several protected areas of contiguous forest and remnant forest fragments of varying sizes ${ }^{4,33}$. These tea plantations span hundreds of hectares and vary in their cultivation practices (chemical use versus organic) and in shade trees (non-native silver oak versus mixed native and non-native species). In this article, we study how bird community structure (species richness, abundance and composition) varies across different kinds of tea plantations and reference rainforest sites in the same landscape. We examined the following hypotheses:

(1) Compared to rainforest sites, tea plantation monocultures with sparse shade trees would have lower bird species richness and abundance, especially of forest-affiliated bird species.

(2) Organic tea plantations would support higher bird species richness and abundance than conventional tea plantations with agrochemical use.

(3) Addition of native shade trees in tea plantations would result in increased bird species richness and abundance, especially of forest-affiliated bird species and a greater similarity in bird species composition with rainforests.

(4) Open-country bird species would respond positively to 'exposed' tea plantations, while forest-affiliated birds would respond positively to mixed-shade tea plantations and rainforests.

Based on our results, we identify cultivation and land-use practices that can promote forest bird diversity in tea plantation and forest landscapes in India and other tropical and sub-tropical regions of the world.

\section{Materials and methods}

\section{Study area and stratification}

The study was conducted in various locations across the Valparai Plateau $\left(220 \mathrm{~km}^{2}, 10^{\circ} 15^{\prime}-10^{\circ} 22^{\prime} \mathrm{N}, 76^{\circ} 52^{\prime}-\right.$ $\left.76^{\circ} 59^{\prime} \mathrm{E}\right)$, a plantation landscape adjoining the $958 \mathrm{~km}^{2}$ Anamalai Tiger Reserve in Tamil Nadu, India. The Valparai Plateau has undulating terrain ranging in elevation between 700 and $1500 \mathrm{~m}$ amsl. The area receives an average of about $2500 \mathrm{~mm}$ annual rainfall, around $70 \%$ of which falls during the southwest monsoon between June and September ${ }^{34}$. The natural vegetation of the plateau is mid-elevation (700-1400 m) tropical wet evergreen rainforest of the Cullenia exarillata-Mesua ferreaPalaquium ellipticum type ${ }^{35}$. Between 1896 and 1930, extensive tracts of tropical rainforest were cleared on the Plateau to establish tea (Camellia sinensis) plantations (which dominate the landscape today), along with coffee
(Coffea arabica, Coffea canephora), cardamom (Elettaria cardamomum) and eucalyptus (Eucalyptus spp.) plantations. Over 45 rainforest fragments (1-300 ha) remain interspersed in the plantation landscape, with both plantations and rainforests continuing to be used by over 150 resident and migrant bird species ${ }^{4,6,33}$.

Tea plantations on the Valparai Plateau are grown as intensive monoculture crops in tightly packed rows of tea with sparsely distributed shade trees planted at roughly $12 \mathrm{~m}$ spacing. Almost all the tea fields in the landscape use primarily a single, non-native tree species as shade tree: the Australian silver oak (Grevillea robusta). Only in a couple of cases do tea plantations have a mix of native and non-native shade trees, because they were converted a few decades ago from shade-grown coffee plantations to tea while retaining most of the shade trees. All the tea on the Valparai Plateau is grown using conventional practices that involve agrochemical use (fertilizers, pesticides and herbicides), except for one organic tea estate belonging to Parry Agro Industries Limited (where only organic fertilizers and pesticides are used, with manual or machine weeding). For the purposes of this study, we surveyed bird communities in five habitat strata.

(1) Conventional tea: Actively managed and harvested tea grown with agrochemical use and alien silver oak G. robusta shade, located in Lower Paralai Estate, mainly planted around 1909-20.

(2) Organic tea: Actively managed and harvested organic tea plantation with silver oak shade, located in Upper Paralai Estate. The tea plantation was first established around the same time as Lower Paralai and was under conventional cultivation till 2006, when it became a certified organic tea estate.

(3) Mixed-shade tea: Actively managed and harvested conventional tea with agrochemical use under a mixed-shade canopy, along the Lower Paralai and Puthuthotam Estate boundary. This was a coffee estate till the 1990s, when it was abandoned for a few years before being converted to a tea plantation in 2001-02 while retaining most of the shade trees. At least 17 native tree species occurred here: Ficus racemosa (cluster fig) was predominant followed by Artocarpus heterophyllus (jack), with few Ficus exasperata, Ficus microcarpa, Ficus virens, Ficus tsjahela, Ficus tinctoria, Cullenia exarillata, Litsea oleoides, Litsea sp., Actinodaphne sp., Persea macrantha, Glochidion sp., Elaeocarpus tuberculatus, Meliosma pinnata, Dimocarpus longan and Vateria indica. The shade trees included four non-native species: Erythrina subumbrans (dadap), Grevillea robusta (silver oak), Spathodea campanulata (African tulip) and Maesopsis eminii (African umbrella tree). 

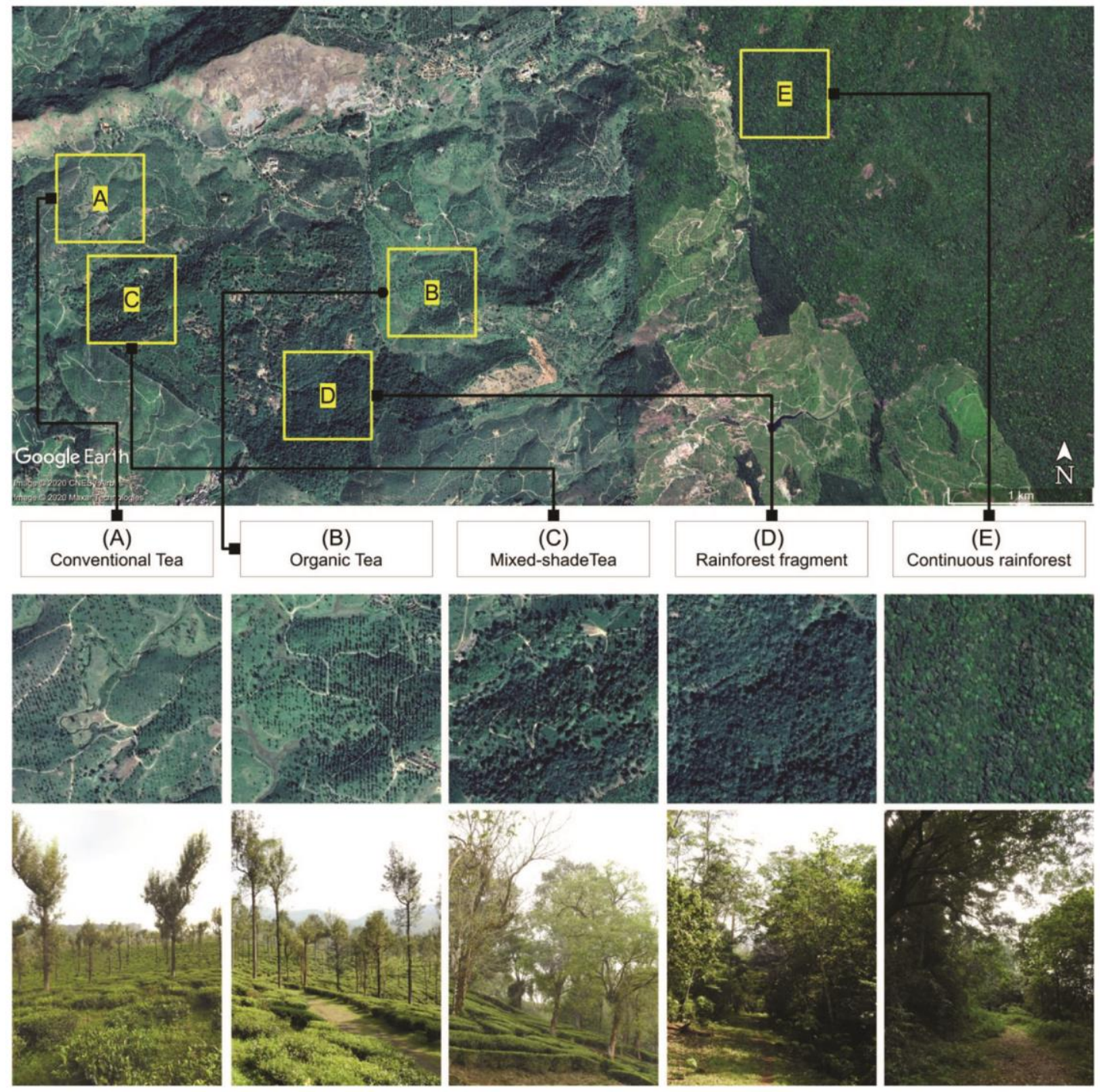

Figure 1. Satellite map of the study area showing location of tea plantations, rainforest fragment, and continuous rainforest study strata (courtesy: Google Earth), with corresponding views of tree canopy cover and photographs illustrating the habitat structure.

(4) Rainforest fragment: A 97-ha rainforest fragment in Puthuthottam Estate adjoining Valparai town and Upper Paralai Estate, with a small portion also adjoining the Lower Paralai Estate. A portion of this fragment had been planted with cardamom and robusta coffee till the $1980 \mathrm{~s}$, after which it has been abandoned. The site is degraded due to past logging (prior to 1992-93) and tree girdling, and continuing fuelwood collection by local people from the adjoining estates and Valparai and Rottikadai townships. This is the nearest fragment $(<1 \mathrm{~km})$ to all three tea plantations in the present study.

(5) Continuous rainforest: A large contiguous tract of rainforest of $>2600$ ha called the IyerpadiAkkamalai complex in the Anamalai Tiger Reserve; sampling was carried out in the Iyerpadi portion of the rainforest adjoining Iyerpadi Tea Estate.
The first four study strata occupied the same elevation range (1050-1200 $\mathrm{m}$ amsl), adjacent to each other, and were less than $2 \mathrm{~km}$ apart, whereas the continuous rainforest was located about $3 \mathrm{~km}$ away at an elevation of 1100-1350 m amsl (Figure 1).

\section{Bird surveys}

In each stratum, we carried out 45 replicate 5-min variable radius point count bird surveys ${ }^{36,37}$ during FebruaryMarch 2016, a period when migrant birds were still present and most residents were active and singing. Surveys were carried out during early morning hours (0630$1030 \mathrm{~h}$ ) with sunny and clear weather when bird activity was high. In each stratum, we surveyed three separate routes, each containing 15 point counts spaced $100 \mathrm{~m}$ apart (due to logistics one route in organic tea was 
surveyed as $13+2$ point counts on two different days) Only one route was surveyed on a given morning. Each subsequent visit to a stratum was spaced on average seven days apart (range 4-10 days) and was used to survey new points along different routes (no resampling of the same point). Point count locations were identified within each stratum, keeping a minimum buffer of $50 \mathrm{~m}$ from habitat edges to minimize edge effects.

Birds detected visually or aurally by two-observer teams were identified to species, counted and their estimated radial distance from the point was noted in the following distance classes (m): 0-5, 5-10, 10-15, 15-20, 20-30, 30-50 and >50. Distances were estimated aurally for calls and with a laser rangefinder for sightings, whenever possible. Observations greater than $50 \mathrm{~m}$ away from the observer were noted only as supplementary information, but discarded from analyses to avoid double counting. Unidentified birds (31 detections totalling 35 individuals) were omitted from analysis. Bird taxonomy follows the Clements Checklist ${ }^{38}$ and the data were uploaded to the eBird India portal (ebird.org/india). Data and analysis code corresponding to this study are also available on Data Dryad (https://doi.org/10.5061/ dryad.b2rbnzsff).

\section{Data analysis}

All analyses were carried out in the $\mathrm{R}$ statistical and programing environment ${ }^{39}$. Species were categorized in terms of habitat affiliation as forest-affiliated (RF) or open country (OC) and also categorized on the basis of their primary foraging layer as aquatic, terrestrial, understorey, mid-storey, canopy and aerial foragers based on earlier research and available natural history information ${ }^{6,40}$. Species were separately categorized according to their primary dietary guild such as frugivores and nectarivores, insectivores, plant- and seed-eating, and predatory or scavenging based on earlier study ${ }^{41}$. Scientific and common names, habitat affiliation, foraging layer and guild categorization of species are presented in the Supplementary Table 1.

Observed bird species richness across strata was examined overall as well as separately for RF and OC species, in relation to primary foraging layer and primary dietary guild. Rarefaction curves to compare bird species richness across strata were estimated using the $\mathrm{R}$ package vegan (version 2.5-6) ${ }^{42}$. We also used the 'specpool' function in package 'vegan' to estimate the number of forest bird species in each stratum using the first-order jackknife estimate and confidence interval (jack1 $\pm 2 \mathrm{SE}$ ) based on the species incidence data across replicate points ${ }^{43}$. We modelled bird abundance (total individuals counted per point) variation across strata using generalized linear models (GLMs) assuming Poisson errors and $\log$ link functions. Pairwise differences between strata were assessed using Tukey HSD multiple comparison tests on the fitted model employing the 'glht' function in package multcomp in $\mathrm{R}$ (ref. 44).

Changes in bird species composition were assessed using the Bray-Curtis dissimilarity index on abundance data pooled by route (15 point counts), with three replicate routes per stratum. Non-metric multidimensional scaling (NMDS) ordination of the Bray-Curtis dissimilarity matrix was used to visualize patterns of change in bird community composition. The dissimilarity matrix was also used to assess statistical significance of difference in bird community composition across the five study strata utilizing analysis of similarities (ANOSIM) ${ }^{45}$ and the function 'anosim' in package 'vegan'.

Patterns of association of individual species with the five habitat strata were assessed using indicator species analysis as implemented in the 'indicspecies' package in $\mathrm{R}$ (version 1.7.9) ${ }^{46}$. We estimated the point biserial correlation coefficient (abundance-based counterpart of the Pearson's phi coefficient, setting func $=$ 'r.g' to correct for unequal group sizes) in the 'indicspecies' package, with 999 permutations to assess statistical significance of the associations with habitat strata.

\section{Results}

\section{Bird species richness}

We recorded 4092 birds (2792 detections) of 103 species, including $59 \mathrm{RF}$ species (1433 detections, 2177 individuals) and 44 OC species (1359 detections, 1915 individuals). Overall bird species richness was lowest in conventional tea (42 species), followed by organic tea (46), and was higher in the other strata: mixed shade tea (59), fragment (61) and continuous rainforest (55).

The frequency of species of different habitat affiliations varied significantly across the five strata $\left(\chi^{2}=47.5\right.$, $\mathrm{d} f=4, P<0.001)$. The percentage of RF versus OC species changed along the same sequence of strata, with more $\mathrm{OC}$ species in conventional tea $(\mathrm{RF}=33 \%, \mathrm{OC}=$ $67 \%)$ and organic tea $(\mathrm{RF}=35 \%, \mathrm{OC}=65 \%)$, intermediate values in mixed shade tea $(\mathrm{RF}=51 \%, \mathrm{OC}=49 \%)$, and more RF species in rainforest fragment $(\mathrm{RF}=74 \%$, $\mathrm{OC}=26 \%)$ and continuous rainforest ( $\mathrm{RF}=87 \%$, $\mathrm{OC}=13 \%$ ). The number of RF species (and the corresponding first-order jackknife estimate, jack $1 \pm 95 \%$ confidence interval) thus showed a clear pattern of increase across the five strata (Figure 2). The RF species richness was similar in conventional tea $(14$, jack $1: 16 \pm 2.8)$ and organic tea $(16$, jack1: $20 \pm 3.9)$, intermediate in mixed shade tea (30, jack1: $35 \pm 5.2)$ and significantly higher in rainforest fragment $(45$, jack1: $55 \pm 7.9)$ and continuous rainforest (48, jack1: $57 \pm 5.9)$.

These trends were also clearly reflected in the rarefaction curves of bird species richness, which indicated that 
when overall bird species richness was considered, mixed shade tea had bird species richness values comparable to the forest strata and higher than the other tea sites (Figure $3 a$ ). When only forest birds were considered, mixed shade tea had intermediate values between the other tea strata that were lower and the forest strata that were higher (Figure $3 \mathrm{~b}$ ). Richness of OC birds showed a contrasting pattern, being high in all tea strata, intermediate in rainforest fragments and very low in continuous rainforest sites (Figure $3 \mathrm{c}$ ). Patterns similar to those revealed by rarefaction and jackknife estimates were observed in bird species density (number of species/point; data not presented here).

The number of bird species categorized by their primary foraging layer varied across the five study strata (Table 1). Tea plantations had more species whose primary foraging layer was aquatic or terrestrial, whereas the rainforest strata had more bird species whose primary foraging layer was in the canopy and mid-storey foliage layers. Species richness of birds that foraged mainly in the shrub layer was highest in continuous rainforest and lowest in conventional tea, and intermediate and similar in other strata.

\section{Bird abundance}

Bird abundance showed significant variation across strata with RF and OC birds showing contrasting patterns (Figure 4). Overall bird abundance (birds/point) was lowest (13.4) in conventional tea and significantly higher in organic tea $(17.8,33 \%$ higher than conventional tea), rainforest fragment $(16.9,26 \%)$ and continuous forest $(18.1,35 \%)$. Overall bird abundance in shade tea $(24.6$, $83 \%$ ) was significantly higher than the other strata. RF

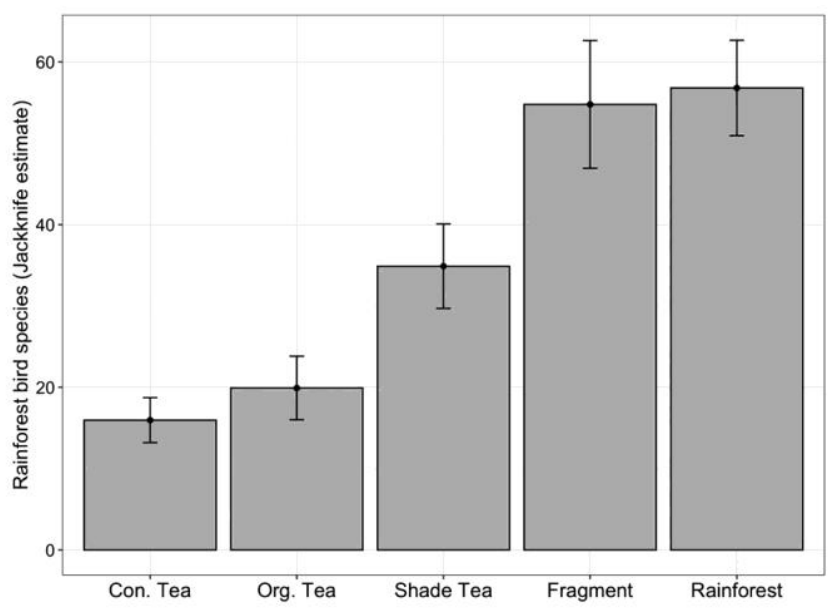

Figure 2. Rainforest bird species richness across the five strata (jackknife estimate). Error bars show 95\% confidence interval ( $\pm 2 \mathrm{SE})$. Con . Tea $=$ Conventional tea; Org. Tea $=$ Organic tea; Shade tea $=$ Mixed shade tea; Fragment $=$ Rainforest fragment; Rainforest $=$ Continuous rainforest. bird abundance was lowest in conventional (2.0) and organic tea (2.8), but substantially higher in shade tea $(13.3,572 \%)$ and rainforest fragments $(13.7,591 \%)$, and highest in continuous rainforest $(16.6,741 \%)$. OC bird abundance, in contrast, was highest in organic tea (15.0, $31 \%$ higher than conventional tea), followed by conventional tea (11.5) and shade tea (11.3), further lower in rainforest fragment $(3.2,72 \%$ lower) and least in continuous rainforest $(1.5,87 \%$ lower; Figure 4$)$.

\section{Bird dietary guilds across strata}

Bird species richness and abundance per point, categorized by primary dietary guild, also varied across the study strata in GLM analyses and Tukey HSD pairwise comparisons (Figure 5). Shade tea, forest fragment and contiguous forest tended to have significantly higher
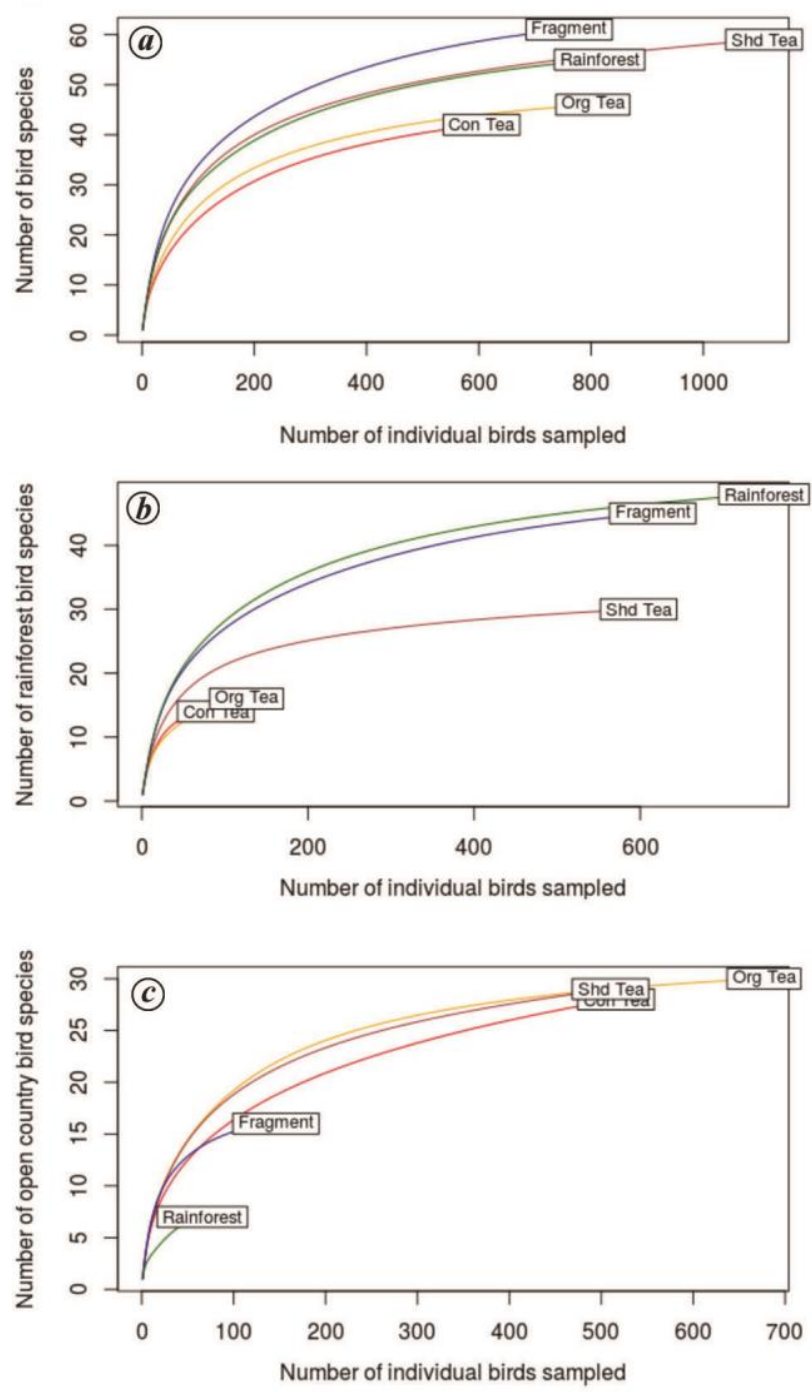

Figure 3. Rarefaction curves of species richness of $(\boldsymbol{a})$ all birds, $(\boldsymbol{b})$ forest birds, and $(\boldsymbol{c})$ open country birds across the three tea plantation strata and two forest strata in the Annamalai Hills, Western Ghats. 
Table 1. Number of bird species of different foraging habits in the five sampled strata in tea plantations and rainforests in the Anamalai Hills, Western Ghats, India

\begin{tabular}{|c|c|c|c|c|c|}
\hline Foraging habit & Conventional tea & Organic tea & Shade tea & Rainforest fragment & Continuous rainforest \\
\hline Aerial & 3 & 3 & 2 & 1 & 2 \\
\hline Aquatic & 5 & 3 & 4 & 2 & 0 \\
\hline Canopy & 10 & 15 & 25 & 30 & 25 \\
\hline Mid-storey & 4 & 3 & 6 & 9 & 9 \\
\hline Shrub & 6 & 8 & 8 & 8 & 9 \\
\hline Terrestrial & 14 & 14 & 14 & 11 & 10 \\
\hline
\end{tabular}
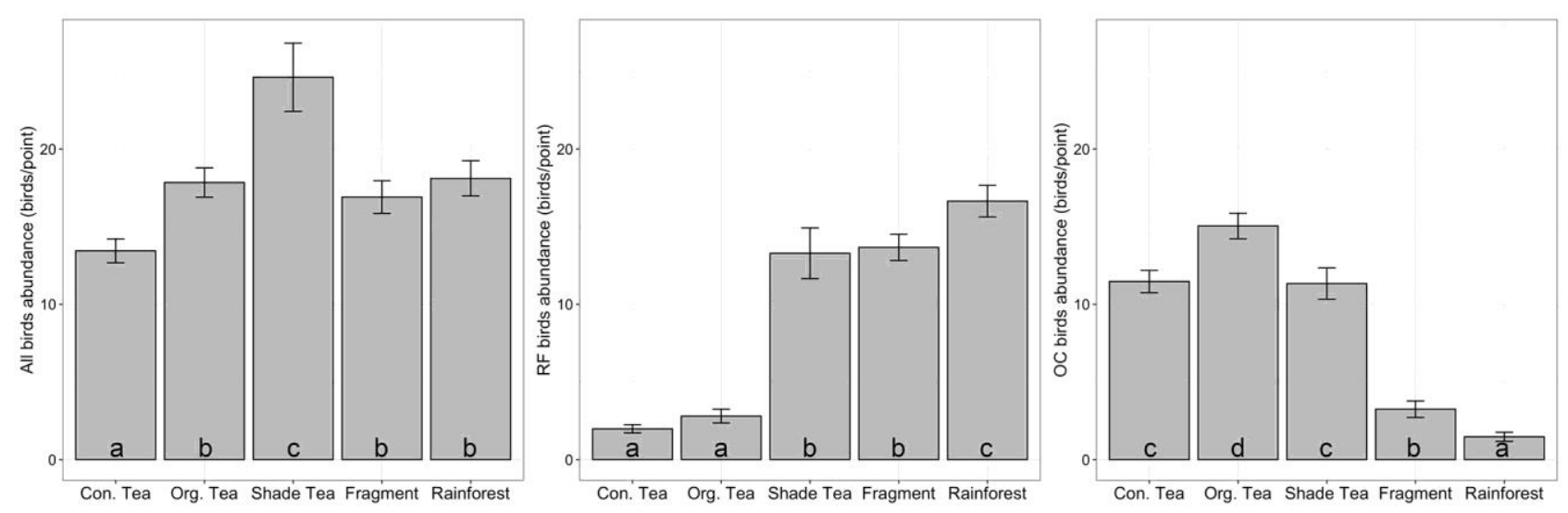

Figure 4. Pattern of bird abundance across the five study strata. The strata marked with different alphabets are statistically signific antly different (Tukey HSD tests, $P<0.05$ ).

richness and abundance of frugivorous and nectarivorous species, while conventional and organic tea plantations had the least. Abundances of frugivores and nectarivores was similarly low in both conventional tea (0.6) and organic tea (0.6), but substantially higher in shade tea (4.8, 707\% higher than conventional and organic tea), rainforest fragment $(6.2,929 \%)$ and contiguous forest $(3.7,515 \%)$. Insectivorous species were more abundant than all other guilds in all strata, but with lowest species richness in conventional tea (3.6) and significantly more in both shade tea (5.0, $40 \%$ higher) and contiguous forest (5.0). Insectivore abundance was lowest in conventional tea $(6.8)$, slightly higher in organic tea $(7.8,20 \%)$ and rainforest fragment $(7.3,11 \%)$, higher in contiguous rainforest $(8.2,26 \%)$ and highest in shade tea $(11.1,70 \%)$. Omnivores and plant- and seed-eaters tended to have higher richness and abundance in tea plantations and continuous forests, than the rainforest fragment. Omnivores showed similar abundances in all strata (between 5.4 and 7.2) except the rainforest fragment, which had significantly fewer omnivores (3.1). Granivore richness was high in organic (0.8) and shade tea (0.7), intermediate in conventional tea (0.4) and rainforest fragment (0.2) and lowest in contiguous forest (0.1). Granivores showed similar abundances in organic and shade tea (1.9), significantly lower in conventional tea (0.8), and lowest in rainforest fragment (0.3) and contiguous forest (0.1). Predatory and scavenging species showed no significant difference in richness across strata and limited variation in abundance across strata being highest in organic tea, although sample size was limited (Figure 5).

\section{Bird community composition}

Change in bird community composition across the five study strata was illustrated by non-metric multi-dimensional scaling (NMDS) ordination using the dissimilarity matrix (Bray-Curtis index). Bray-Curtis dissimilarity was calculated using abundance data aggregated for each route of 15 point count samples, with three such routes in each stratum. The ordination graph indicates little difference in the bird community composition between conventional and organic tea, although shade tea plantations were distinct from the other two tea strata (Figure 6, stress $=0.052$ ). The rainforest fragment and continuous rainforest were distinct from each other and the tea plantations, with shade tea plantations being more similar to the rainforest fragment. Analysis of similarities indicated that the differences in community composition across the five strata were statistically significant (ANOSIM $R=$ $0.8696, P<0.001)$.

\section{Indicator species analysis}

Indicator species analysis using the phi coefficient revealed significant associations with habitat strata among 54 species at a significance level of $P<0.05(+8$ species 

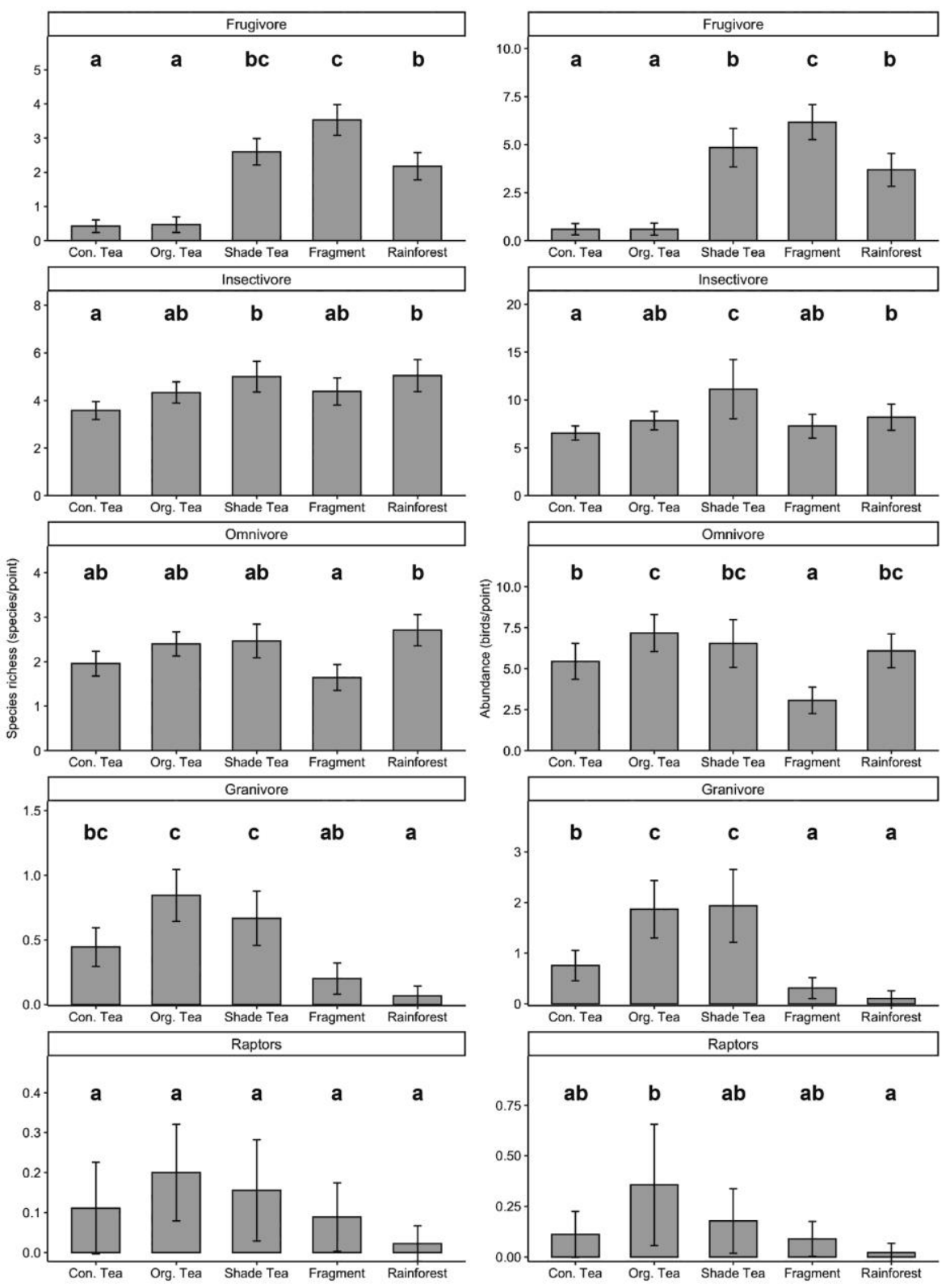

Figure 5. Foraging guild-wise richness and abundance per point across the five study strata. The strata marked with different alphabets are statistically significantly different (Tukey HSD tests, $P<0.05$ ). Note that the $Y$-axes of the plots are not in the same scale.

at $0.05<P<0.10$, included here for illustrative purposes). Of the $54(+8)$ species overall, $35(+2)$ species were significantly associated with one stratum, 16 species $(+5)$ with two strata and $8(+1)$ with three strata (Table 2).

Several common OC birds were either broadly associated with all tea plantation strata: Red-whiskered Bulbul, Blyth's Reed-Warbler and Common Tailorbird, or to conventional and organic tea plantations: Jungle Myna, Oriental Magpie-Robin, Plum-headed Parakeet and Grey Wagtail (Table 2). Species associated with the organic and shade tea plantations included Brown Shrike, Streakthroated Woodpecker and Rufous Babbler, the latter being a forest-edge endemic bird species. Birds signifi- cantly associated with a single kind of tea plantation included aerial, terrestrial and understorey species (e.g. Eurasian Hoopoe, Ashy Prinia and Greater Coucal), while some canopy species were associated only with shade tea (Ashy Drongo and Golden-fronted Leafbird).

Few birds were associated jointly with tea and forest strata. The Large-billed Crow was associated with conventional and organic tea and the rainforest fragment. Five species were associated with shade tea and the two forest strata (Oriental White-Eye, Nilgiri Flowerpecker, White-cheeked Barbet, Greenish Warbler and Velvetfronted Nuthatch). These latter five species were rainforest birds, as were 27 other species associated with rainforest 
fragment and/or continuous forests (Table 2). The 27 forest-associated birds included a number of endemic and specialized species such as White-bellied Blue-Flycatcher, Brown-cheeked Fulvetta, Asian Fairy-Bluebird and Malabar Grey Hornbill.

\section{Discussion}

Tea plantations as intensive monoculture with sparse tree cover of a single tree species (silver oak) have a much lower diversity of birds than forests in the same landscape - as noted in an earlier study from South India ${ }^{4}$. A similar pattern of low bird diversity in tea plantations relative to forests has been reported from Sri Lanka ${ }^{16,47,48}$, Peninsular Malaysia ${ }^{17}$ and North East India, where 3-5 tree species may be used for shade ${ }^{49,50}$. Earlier studies have not, however, documented variation in bird communities in different kinds of tea plantations. The present study from the Anamalai Hills reveals that relative to conventional tea plantations, bird diversity and abundance are substantially higher in mixed-shade tea and only moderately higher in organic tea.

The generally beneficial effects of organic farming on biological diversity have been established in a crosssection of studies, indicating a $30 \%$ higher species richness $^{23,27}$ and $50 \%$ higher abundance of taxa on average in organic farms compared to conventional farms ${ }^{23}$. For birds, an average increase in species richness by $20.5 \%$ was noted across 17 studies (table S2 in Tuck et al. ${ }^{27}$ ). In consonance with this general pattern, in the Anamalai plantations, we found relatively modest gains in organic tea relative to conventional tea, with a small increase in species richness (10\% overall, $25 \%$ in forest bird species richness jackknife estimate) and a moderate increase in bird abundance (all birds: 33\%, forest birds: 40\%). Unsurprisingly, given the sparse canopy and absence of mid-

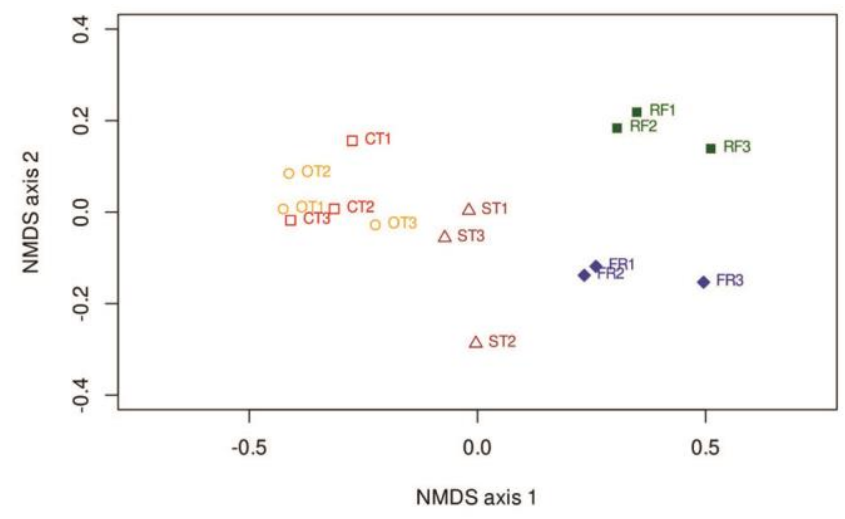

Figure 6. Bird community change across tea plantations and forest strata illustrated using non-metric multi-dimensional scaling ordination. Each point corresponds to a route with 15 point count samples. CT, Conventional tea; OT, Organic tea; ST, Mixed-shade tea; FR, Rainforest fragment; RF, Continuous rainforest. Numbers against the site codes refer to replicate route. storey trees, a larger fraction of birds in conventional and organic tea are those of terrestrial or shrub layer (Table 1). Although these birds are primarily insectivorous or omnivorous, conventional tea is likely to have lower insect prey abundance in tea bushes that are regularly sprayed with pesticides, besides poor ground cover due to herbicide application, which may lead to a decline in bird species richness and abundance. Insectivorous bird abundance was slightly higher in organic tea possibly due to increased ground cover and prey abundance, which may also explain why some birds that forage off terrestrial substrates (Spotted Dove and Long-tailed Shrike) or in the shrub layer (Ashy Prinia and Greater Coucal) showed a stronger association with organic tea (Table 2).

More than the moderate gains in organic tea, however, were the larger gains in bird species richness and abundance (particularly of forest birds) in the mixed-shade tea plantations, suggesting that the incorporation of native trees introduces a habitat element that benefits many more bird species. This was supported by the occurrence of more canopy species as well as birds of shrub and understorey in mixed-shade tea plantations (Table 1). Mixed-shade tea also supports more insectivorous, frugivorous and nectarivorous species than either conventional or organic tea plantations (Figure 5). The influence of higher native tree species diversity or density/tree cover in supporting higher diversity of birds, including forestaffiliated species was suggested for tea plantations in Sri Lanka $^{48}$ and India ${ }^{50}$. In tropical forest regions, tree density, diversity and stature help sustain bird diversity by contributing to habitat structure and floristics in different production landscapes, including paddy fields (in Ratnagiri, Maharashtra ${ }^{31}$ ), tree plantations (in Africa ${ }^{51}$ and India ${ }^{10}$ ), coffee plantations (in the Neotropics ${ }^{52}$, India ${ }^{6,8}$, but not Africa $^{53}$ ), agroforestry ${ }^{3,54}$ and countryside habitats $^{55}$.

While two-thirds of the bird species in organic and conventional tea were $\mathrm{OC}$, this proportion dropped to about half in mixed shade tea as RF species increased along with a significant shift in bird community composition. While abundances of OC birds are similar between conventional and mixed-shade tea plantations (Figure 4), there seems to be a slight shift in OC bird species between the two strata (Table 2). Native trees in mixedshade tea were not heavily lopped as in the other tea plantations; so they presented additional branching substrate, more foliage, nectar, fruit and seed resources when in flower or fruit. Availability of nectar and fruit resources probably influences the occurrence of nectarivorous and frugivorous birds in tea plantations ${ }^{50}$. The mixed-shade tea had a number of flowering trees and several fleshyfruited tree species, including at least six species of wild figs ( $F$. tsjahela, $F$. racemosa, $F$. virens, $F$. exasperata, F. microcarpa, F. tinctoria, P. macrantha, Glochidion sp., Actinodaphne sp., L. oleoides, Litsea sp.). The availability of these tree species likely contributed to the 
RESEARCH ARTICLES

Table 2. Association of bird species with habitat strata as revealed by the phi coefficient in indicator species analysis. Table cells are shaded dark grey if the species - habitat association is significant at $P<0.05$ and light grey if $0.05<P<0.10$

\begin{tabular}{|c|c|c|c|c|c|c|c|}
\hline Species & Stat & $P$ & $\begin{array}{c}\text { Conventional } \\
\text { tea }\end{array}$ & $\begin{array}{c}\text { Organic } \\
\text { tea }\end{array}$ & $\begin{array}{c}\text { Shade } \\
\text { tea }\end{array}$ & $\begin{array}{l}\text { Rainforest } \\
\text { fragment }\end{array}$ & $\begin{array}{c}\text { Continuous } \\
\text { rainforest }\end{array}$ \\
\hline Eurasian Hoopoe & 0.289 & $0.001 * * *$ & & & & & \\
\hline Dusky Crag-Martin & 0.232 & $0.036^{*}$ & & & & & \\
\hline Jungle Myna & 0.522 & $0.001 * * *$ & & & & & \\
\hline Oriental Magpie-Robin & 0.397 & $0.001 * * *$ & & & & & \\
\hline Plum-headed Parakeet & 0.249 & $0.005 * *$ & & & & & \\
\hline Grey Wagtail & 0.233 & $0.010^{* *}$ & & & & & \\
\hline Red-whiskered Bulbul & 0.555 & $0.001 * * *$ & & & & & \\
\hline Blyth's Reed-Warbler & 0.545 & $0.001 * * *$ & & & & & \\
\hline Common Tailorbird & 0.266 & $0.001 * * *$ & & & & & \\
\hline Large-billed Crow & 0.281 & $0.001 * * *$ & & & & & \\
\hline Long-tailed Shrike & 0.484 & $0.001 * * *$ & & & & & \\
\hline Spotted Dove & 0.452 & $0.001 * * *$ & & & & & \\
\hline Ashy Prinia & 0.310 & $0.001 * * *$ & & & & & \\
\hline Thick-billed Warbler & 0.259 & $0.005^{* *}$ & & & & & \\
\hline House Crow & 0.225 & $0.002 * *$ & & & & & \\
\hline Greater Coucal & 0.213 & $0.025^{*}$ & & & & & \\
\hline Indian Golden Oriole & 0.185 & $0.097+$ & & & & & \\
\hline Streak-throated Woodpecker & 0.322 & $0.001 * * *$ & & & & & \\
\hline Brown Shrike & 0.285 & $0.001 * * *$ & & & & & \\
\hline Rufous Babbler & 0.275 & $0.002 * *$ & & & & & \\
\hline Purple Sunbird & 0.176 & $0.068+$ & & & & & \\
\hline Common Rosefinch & 0.469 & $0.001 * * *$ & & & & & \\
\hline Indian Swiftlet & 0.290 & $0.003 * *$ & & & & & \\
\hline Grey Junglefowl & 0.288 & $0.001 * * *$ & & & & & \\
\hline Ashy Drongo & 0.254 & $0.007 * *$ & & & & & \\
\hline Golden-fronted Leafbird & 0.239 & $0.014^{*}$ & & & & & \\
\hline Indian Blackbird & 0.202 & $0.038^{*}$ & & & & & \\
\hline Orange-headed Thrush & 0.231 & $0.010^{* *}$ & & & & & \\
\hline Asian Brown Flycatcher & 0.219 & $0.033^{*}$ & & & & & \\
\hline Chestnut-headed Bee-eater & 0.172 & $0.096+$ & & & & & \\
\hline Oriental White-Eye & 0.370 & $0.001 * * *$ & & & & & \\
\hline Nilgiri Flowerpecker & 0.570 & $0.001 * * *$ & & & & & \\
\hline White-cheeked Barbet & 0.378 & $0.001 * * *$ & & & & & \\
\hline Greenish Warbler & 0.269 & $0.002 * *$ & & & & & \\
\hline Velvet-fronted Nuthatch & 0.258 & $0.002 * *$ & & & & & \\
\hline Greater Racket-tailed Drongo & 0.540 & $0.001 * * *$ & & & & & \\
\hline Malabar Barbet & 0.496 & $0.001 * * *$ & & & & & \\
\hline Southern Hill Myna & 0.478 & $0.001 * * *$ & & & & & \\
\hline Orange Minivet & 0.388 & $0.001 * * *$ & & & & & \\
\hline Malabar Grey Hornbill & 0.383 & $0.001 * * *$ & & & & & \\
\hline Grey-fronted Green-Pigeon & 0.333 & $0.001 * * *$ & & & & & \\
\hline Malabar Whistling-Thrush & 0.321 & $0.001 * * *$ & & & & & \\
\hline Vernal Hanging-Parrot & 0.289 & $0.001 * * *$ & & & & & \\
\hline Asian Fairy-bluebird & 0.274 & $0.001 * * *$ & & & & & \\
\hline Asian Paradise-Flycatcher & 0.185 & $0.091+$ & & & & & \\
\hline Brown-breasted Flycatcher & 0.185 & $0.082+$ & & & & & \\
\hline Emerald Dove & 0.185 & $0.099+$ & & & & & \\
\hline Greater Flameback & 0.185 & $0.075+$ & & & & & \\
\hline Yellow-browed Bulbul & 0.687 & $0.001 * * *$ & & & & & \\
\hline Square-tailed Bulbul & 0.598 & $0.001 * * *$ & & & & & \\
\hline Crimson-backed Sunbird & 0.580 & $0.001 * * *$ & & & & & \\
\hline Large-billed Leaf Warbler & 0.555 & $0.001 * * *$ & & & & & \\
\hline Mountain Imperial-Pigeon & 0.434 & $0.001 * * *$ & & & & & \\
\hline Puff-throated Babbler & 0.427 & $0.001 * * *$ & & & & & \\
\hline Brown-cheeked Fulvetta & 0.424 & $0.001 * * *$ & & & & & \\
\hline Grey-headed Canary-Flycatcher & 0.400 & $0.001 * * *$ & & & & & \\
\hline Little Spiderhunter & 0.317 & $0.002 * *$ & & & & & \\
\hline Black-and-rufous Flycatcher & 0.312 & $0.003^{* *}$ & & & & & \\
\hline Nilgiri Flycatcher & 0.309 & $0.001 * * *$ & & & & & \\
\hline Dark-fronted Babbler & 0.294 & $0.001 * * *$ & & & & & \\
\hline White-bellied Blue-Flycatcher & 0.222 & $0.018^{*}$ & & & & & \\
\hline Indian Scimitar-Babbler & 0.182 & $0.063+$ & & & & & \\
\hline
\end{tabular}


association with mixed-shade tea of bird species such as Common Rosefinch, Ashy Drongo and Golden-fronted Leafbird that forage in the tree canopy, besides species such as White-cheeked Barbet and Nilgiri Flowerpecker that also occurred in forests (Table 2).

Our study findings also indicate that forest fragments, despite degradation and ongoing anthropogenic pressure, are important refuges for rainforest birds, with their species richness fairly similar to that in continuous forest sites. This is in concurrence with other studies from this region $^{4,6}$. While overall richness is similar between the two strata, there is a notable shift in bird community structure due to the occurrence of a greater proportion and abundance of OC birds in the fragment (Table 2 and Figure 6). Forest fragments retain a degree of mid-storey structure and complexity as in contiguous forests, which is absent in all tea plantations and this may account for the absence of bird species (such as Yellow-browed Bulbul, Brown-cheeked Fulvetta) that specialize in foraging at this level (Table 1). This, along with the higher diversity of rainforest birds in forest strata, indicates that tea plantations, even under mixed native shade, cannot be a replacement for fragmented or intact forests. While conversion of existing conventionally managed tea estates to organic tea or diverse native shade tea can be beneficial for biodiversity, any conversion of fragmented or contiguous forests to tea plantations will have detrimental effects on birds.

Changes in bird community composition and patterns of habitat association of individual species support the conclusion that the bird community of monoculture tea plantations with silver oak is composed mainly of OC birds derived from a wider regional species pool, unlike the forest fragment and continuous forest sites that are composed mainly of RF birds from the species pool in the local landscape. This pattern is related to the habitat alteration in tea to a more open and two-layered habitat (tea shrubs, shade trees) that resembles open and drier forest habitats with sparse tree cover, distinct from the dense and multi-layered vegetation typical of the rainforest sites $^{4}$. Most OC bird species are common and widespread species with a much larger distributional range, unlike the RF birds that include several endemic species closely associated with dense forest habitats which are of higher conservation priority ${ }^{6}$. The entry of such OC bird species into a previously forested landscape following habitat alteration, also noted in other tropical Asian forests ${ }^{17}$, has been termed biological infiltration and is a matter of conservation concern when it results in the loss of rarer, forest-specialist or restricted-range species $^{6,56}$. Significantly, a number of forest birds occurred in mixed-shade tea, including at least seven species also associated with the other rainforest strata (Table 2), suggesting that the incorporation of native shade trees minimizes the degree of habitat alteration and attracts birds from the species pool of forest birds. Recent analyses of bird population trends indicate range-wide decline in endemic birds of the Western Ghats ${ }^{57}$. As over $1100 \mathrm{~km}^{2}$ of tea plantations occupy previously forested landscapes in this region, the adoption of such improved land-use practices can aid bird conservation at the landscape level.

Globally, over $6.5 \mathrm{~m}$ ha is under tea production and the area under tea plantations continues to increase ${ }^{19}$. As tea cultivation occurs mainly in tropical and montane regions noted for their high biodiversity, it has raised concerns related to sustainability and conservation of native spe$\operatorname{cies}^{22}$. The significance of native shade trees in farms and human-use landscapes for forest bird conservation is increasingly recognized in tropical regions worldwide $^{18,58,59}$. Native trees are also important for sustainability in tea and coffee plantations, where they may bring multiple benefits such as increased yields, improved soil nutrition through decomposition of shade tree leaf litter, higher native biodiversity and pest control ${ }^{54,60,61}$. In regions such as South India where tea is cultivated with a single non-native tree species like silver oak, adopting additional native shade trees can enable plantations to support forest bird conservation in landscapes outside protected reserves, especially in regions of high biodiversity and conservation value. At the very least, retaining the strangler fig species that naturally germinate on silveroaks would in the long-term benefit bird and insect conservation at a landscape level even in intensive production landscapes. As mixed-shade plantations support higher species richness and abundance of birds that predate on insects, adoption of mixed native shade in tea plantations is likely to help in pest control as evidenced in coffee plantations ${ }^{32,62,63}$. This is an aspect of integrated pest management that deserves further research attention in tea plantations ${ }^{15}$. Tea plantations that are both organic and have mixed native shade trees could possibly be even better for forest bird communities, although such a site was unavailable for comparison in the present study. Conversion of conventionally managed to organic estates could bring environmental and commercial benefits (through premiums from organic certification) in the short term, while incorporating multi-species native shade trees could help in carbon sequestration ${ }^{64,65}$ and benefit biodiversity (present study) in the long term. Although the relationship between shade and tea yield, physiology and quality is complex, past research has underscored the importance of moderate shade for tea production and climate-smart agriculture ${ }^{66}$. The literature on shade in tea has so far not explored the effects on tea production of mixed shade with diverse native species. Most tea plantations therefore continue to rely on a single shade tree species such as silver oak (in South India, Sri Lanka, parts of Southeast Asia and Africa), or a handful of species such as Albizia odoratissima, A. chinensis, A. lebbeck and Derris robusta (in Assam, NE India). Mixed native shade is observed only in relatively small areas, e.g. where shade coffee estates were converted to tea 
while retaining the trees (as in one of our study sites), or in small-holder farms where useful native trees (e.g. jack Artocarpus heterophyllus) are retained in the tea fields (pers. obs.).

As this study was conducted over a relatively short period during late winter and early spring, future research that extends to other seasons, examines inter-annual variability and replicates surveys across other teagrowing regions can help assess the generality of our findings. This can also shed light on the differences between migrants and resident birds as well as on seasonal variation in guild-level patterns. Landscape-level influences, such as the effects of proximity to forest fragments, extent of surrounding forest cover or effects of different adjoining land uses or landscape elements (such as Eucalyptus plantations) also need to be explored in future work. For insectivorous birds, combining surveys with invertebrate population sampling and exclusion experiments can help reveal whether birds are tracking availability of insect prey and playing a role in pest control. Monitoring birds in relation to timing of agrochemical application can also help reveal if bird responses vary in relation to time elapsed since chemical use, which would imply that the magnitude of differences detected between conventional and organic tea would depend on when the surveys are conducted. There has been limited research on birds in tea plantations worldwide and further work on the above aspects can help fill existing knowledge gaps.

1. Bhagwat, S. A., Willis, K. J., Birks, H. J. B. and Whittaker, R. J., Agroforestry: a refuge for tropical biodiversity? Trends Ecol. Evol., 2008, 23, 261-267.

2. Koh, L. P. and Gardner, T. A., Conservation in human-modified landscapes. In Conservation Biology for All (eds Sodhi, N. S. and Ehrlich, P. R.), Oxford University Press, Oxford, 2010, pp. 236261.

3. Thiollay, J., The role of traditional agroforests in the conservation of rain forest bird diversity in Sumatra. Conserv. Biol., 1995, 9, 335-353.

4. Sidhu, S., Raman, T. R. S. and Goodale, E., Effects of plantations and home-gardens on tropical forest bird communities and mixedspecies bird flocks in the southern Western Ghats. J. Bombay Nat. Hist. Soc., 2010, 107, 91-108.

5. Goodale, E. et al., The response of birds and mixed-species bird flocks to human-modified landscapes in Sri Lanka and southern India. For. Ecol. Manage., 2014, 329, 384-392.

6. Raman, T. R. S., Effects of habitat structure and adjacent habitats on birds in tropical rainforest fragments and shaded plantations in the Western Ghats, India. Biodivers. Conserv., 2006, 15, 15771607.

7. Sreekar, R., Mohan, A., Das, S., Agarwal, P. and Vivek, R., Natural windbreaks sustain bird diversity in a tea-dominated Landscape. PLOS ONE, 2013, 8, 4-11.

8. Anand, M. O., Krishnaswamy, J. and Das, A., Proximity to forests drives bird conservation value of coffee plantations: implications for certification. Ecol. Appl., 2008, 18, 1754-1763.

9. Zhang, M., Chang, C. and Quan, R., Natural forest at landscape scale is most important for bird conservation in rubber plantation. Biol. Conserv., 2017, 210, 243-252.
10. Raman, T. R. S. and Sukumar, R., Responses of tropical rainforest birds to abandoned plantations, edges and logged forest in the Western Ghats, India. Anim. Conserv., 2002, 5, 201-216.

11. Shahabuddin, G. and Kumar, R., Influence of anthropogenic disturbance on bird communities in a tropical dry forest: role of vegetation structure. Anim. Conserv., 2006, 9, 404-413.

12. Mandal, J. and Raman, T. R. S., Shifting agriculture supports more tropical forest birds than oil palm or teak plantations in Mizoram, northeast India. Condor Ornithol. Appl., 2016, 18, 345-359.

13. Koh, L. P., Can oil palm plantations be made more hospitable for forest butterflies and birds? J. Appl. Ecol., 2008, 45, 1002-1009.

14. Péron, G. and Crochet, P. A., Edge effect and structure of mixedspecies bird flocks in an Afrotropical lowland forest. J. Ornithol., 2009, 150, 585-599.

15. Sinu, P. A., Avian pest control in tea plantations of sub-Himalayan plains of Northeast India: mixed-species foraging flock matters. Biol. Control, 2011, 58, 362-366.

16. Subasinghe, K., Sumanapala, A. P. and Weerawardhena, S. R., The impact of forest conversion on bird communities in the northern flank of the Knuckles Mountain Forest Range, Sri Lanka. J. Asia-Pac. Biodivers., 2014, 7, 367-373.

17. Soh, M. C. K., Sodhi, N. S. and Lim, S. L. H., High sensitivity of montane bird communities to habitat disturbance in Peninsular Malaysia. Biol. Conserv., 2006, 129, 149-166.

18. Deikumah, J. P., Kwafo, R., and Konadu, V. A., Land use types influenced avian assemblage structure in a forest-agriculture landscape in Ghana. Ecol. Evol., 2017, 7, 8685-8697.

19. FAO, FAOSTAT: Food and Agriculture Data. FAOSTAT Food Agric. Data, 2020.

20. Tea Board, Tea Statistics 2003-2004. Tea Board, Kolkata, 2006.

21. Tea Board, Statistics. Tea Statistics, 2020.

22. Clay, J., World Agriculture and the Environment, Island Press, Ithaca, 2004.

23. Bengtsson, J., Ahnström, J. and Weibull, A.-C., The effects of organic agriculture on biodiversity and abundance: a metaanalysis. J. Appl. Ecol., 2005, 42, 261-269.

24. Fuller, R. J. et al., Benefits of organic farming to biodiversity vary among taxa. Biol. Lett., 2005, 1, 431-434.

25. Hole, D. G., Perkins, A. J., Wilson, J. D., Alexander, I. H., Grice, P. V. and Evans, A. D., Does organic farming benefit biodiversity? Biol. Conserv., 2005, 122, 113-130.

26. Kirk, D. A., Lindsay, K. E. and Brook, R. W., Risk of agricultural practices and habitat change to farmland birds. Avian Conserv. Ecol., 2011, 6, 5.

27. Tuck, S. L., Winqvist, C., Mota, F., Ahnström, J., Turnbull, L. A. and Bengtsson, J., Land-use intensity and the effects of organic farming on biodiversity: a hierarchical meta-analysis. J. Appl. Ecol., 2014, 51, 746-755.

28. Padoa-Schioppa, E., Baietto, M., Massa, R. and Bottoni, L., Bird communities as bioindicators: the focal species concept in agricultural landscapes. Ecol. Indic., 2006, 6, 83-93.

29. Whelan, C. J., Wenny, D. G. and Marquis, R. J., Ecosystem services provided by birds. Ann. N. Y. Acad. Sci., 2008, 1134, 25-60.

30. Philpott, S. M. et al., Functional richness and ecosystem services: bird predation on arthropods in tropical agroecosystems. Ecol. Appl., 2009, 19, 1858-1867.

31. Mandan, J., Patil, V., Narkhede, S., Gunaga, R. and Bhave, S., Birds: a bio-control agent in farmland ecosystem. Indian J. Agrofor., 2014, 16, 15-20.

32. Milligan, M. C., Johnson, M. D., Garfinkel, M., Smith, C. J. and Njoroge, P., Quantifying pest control services by birds and ants in Kenyan coffee farms. Biol. Conserv., 2016, 194, 58-65.

33. Mudappa, D., Kumar, M. A. and Raman, T. R. S., Restoring nature: wildlife conservation in landscapes fragmented by plantation crops in India. In Nature Without Borders (eds Rangarajan, M., Madhusudan, M. D. and Shahabuddin, G.), Orient Black Swan, New Delhi, 2014, pp. 178-214. 
34. Rathod, I. M. and Aruchamy, S., Spatial analysis of rainfall variation in Coimbatore district Tamil Nadu using GIS. Int. J. Geomat. Geosci., 2010, 1, 106-118.

35. Pascal, J. P., Wet Evergreen Forests of the Western Ghats of India: Ecology, Structure, Floristic Composition and Succession, Institute Français de Pondichéry, 1988.

36. Bibby, C., Burgess, N., Hill, D. and Mustoe, S., Bird Census Techniques - 2nd Edition, Academic Press, Amsterdam, 2000.

37. Buckland, S. T., Rexstad, E. A., Marques, T. A. and Oedekoven, C. S., Distance Sampling: Methods and Applications, Springer International Publishing, 2015.

38. Clements, J. F. et al., The eBird/Clements Checklist of Birds of the World: v2019, 2019; https://www.birds.cornell.edu/ clementschecklist/download/ (accessed on 1 January 2020).

39. R Core Team, R: A Language and Environment for Statistical Computing, R Foundation for Statistical Computing, Vienna, Austria, 2020; https://www.R-project.org/

40. Ali, S. and Ripley, S. D., Handbook of the Birds of India and Pakistan, Compact edition. Oxford University Press, Delhi, 1983.

41. Wilman, H., Belmaker, J., Simpson, J., de la Rosa, C., Rivadeneira M. M. and Jetz, W., EltonTraits 1.0: Species-level foraging attributes of the world's birds and mammals. Ecology, 2014, 95, 20272027

42. Oksanen, J. et al., Vegan: Community Ecology Package, 2019; https://CRAN.R-project.org/package=vegan

43. Gotelli, N. J. and Colwell, R. K., Estimating species richness. In Frontiers in Measuring Biodiversity (eds Magurran, A. E. and McGill, B. J.), Oxford University Press, New York, 2011, pp. 3954.

44. Hothorn, T., Bretz, F. and Westfall, P., Simultaneous inference in general parametric models. Biom. J., 2008, 50, 346-363.

45. Clarke, K. R., Non-parametric multivariate analyses of changes in community structure. Aust. J. Ecol., 1993, 18, 117-143.

46. De Cáceres, M. and Legendre, P., Associations between species and groups of sites: indices and statistical inference. Ecology, 2009, 90, 3566-3574.

47. Kottawa-Arachchi, J. D., Gamage, R. N., Ariyarathne, H. A. C. K and Jayathilake, G. G., Avifaunal diversity in a tea plantation ecosystem in the up-country of Sri Lanka. In Proceedings of the International Forestry and Environment Symposium 2010 of Forestry and Environmental Science, University of Sri Jayewardenepura, Sri Lanka, 2010, pp. 318-327.

48. Kottawa-Arachchi, J. D. and Gamage, R. N., Avifaunal diversity and bird community responses to man-made habitats in St Coombs Tea Estate, Sri Lanka. J. Threat. Taxa, 2015, 7, 6878-6890.

49. Ahmed, A. and Dey, M., A checklist of the winter bird community in different habitat types of Rosekandy Tea Estate of Assam, India. J. Threat. Taxa, 2014, 6, 5478-5484.

50. Yashmita-Ulman, Sharma, M. and Kumar, A., Agroforestry systems as habitat for avian species: assessing its role in conservation. Proc. Zool. Soc., 2018, 71, 127-145.

51. Farwig, N., Sajita, N. and Böhning-Gaese, K., Conservation value of forest plantations for bird communities in western Kenya. For. Ecol. Manage., 2008, 255, 3885-3892.

52. Tejeda-Cruz, C. and Sutherland, W. J., Bird responses to shade coffee production. Anim. Conserv., 2004, 7, 169-179.

53. Smith, C. et al., Bird communities in sun and shade coffee farms in Kenya. Glob. Ecol. Conserv., 2015, 4, 479-490.

54. Waltert, M., Mardiastuti, A. and Mühlenberg, M., Effects of land use on bird species richness in Sulawesi, Indonesia. Conserv. Biol., 2004, 18, 1339-1346.
55. Hughes, J. B., Daily, G. and Ehrlich, P., Conservation of tropical forest birds in countryside habitats. Ecol. Lett., 2002, 5, 121-129.

56. Raman, T. R. S., Community ecology and conservation of midelevation tropical rainforest bird communities in the southern Western Ghats, India. Ph.D. thesis, Indian Institute of Science, Bangalore, 2001.

57. SoIB, State of India's Birds, 2020: Range, Trends and Conservation Status, The SoIB Partnership, 2020, p. 50.

58. Harvey, C. A. et al., Patterns of animal diversity in different forms of tree cover in agricultural landscapes. Ecol. Appl., 2006, 16, 1986-1999.

59. Mendoza, S. V. et al., Consistency in bird use of tree cover across tropical agricultural landscapes. Ecol. Appl., 2014, 24, 158-168.

60. Leakey, R. R. B., The role of trees in agroecology and sustainable agriculture in the tropics. Annu. Rev. Phytopathol., 2014, 52, 113133.

61. Barrios, E. et al., Contribution of trees to the conservation of biodiversity and ecosystem services in agricultural landscapes. Int. J. Biodivers. Sci. Ecosyst. Serv. Manage., 2018, 14, 1-16.

62. Karp, D. S. et al., Forest bolsters bird abundance, pest control and coffee yield. Ecol. Lett., 2013, 16, 1339-1347.

63. Librán-Embid, F., De Coster, G. and Metzger, J. P., Effects of bird and bat exclusion on coffee pest control at multiple spatial scales. Landsc. Ecol., 2017, 32, 1907-1920.

64. Kalita, R. M., Das, A. K. and Nath, A. J., Carbon stock and sequestration potential in biomass of tea agroforestry system in Barak Valley, Assam, North East India. Int. J. Ecol. Environ. Sci., 2017, 42, 107-114.

65. Kalita, R., Das, A. and Nath, A., Role of smallholder tea growers in carbon sink management. Curr. Sci., 2019, 116, 1560-1566.

66. Mohotti, A. J., Pushpakumara, G. and Singh, V. P., Shade in tea plantations: a new dimension with an agroforestry approach for a climate-smart agricultural landscape system. In Agricultural Research for Sustainable Food Systems in Sri Lanka: Volume 2: A Pursuit for Advancements (eds De Silva, R. P. et al.), Springer, Singapore, 2020, pp. 67-87.

ACKNOWLEDGEMENTS. This work was carried out as part of the rainforest restoration programme of the Nature Conservation Foundation, supported by Rohini Nilekani Philanthropies, A. M. M. Murugappa Chettiar Research Centre and Arvind Datar. T.R.S.R. acknowledges funding from the Science and Engineering Board (SERB), Government of India (Research grant: EMR/2016/007968). We thank plantation management of Parry Agro and Tea Estates India Limited for permissions to work in the estates, and the Tamil Nadu Forest Department for permits to work in the Anamalai Tiger Reserve. We thank our NCF colleagues Kulbhshansingh Suryawanshi, Akshay Surendra and Aparna Krishnan for discussions related to data analysis and M. Ananda Kumar, Ashni Dhawale, Anand Osuri, Pooja Pawar, Ganesh Raghunathan, M. Ananda Kumar, K. Srinivasan, A. Sathish Kumar and Mrinalini K. Siddhartha for discussions and help. We also thank Manikaraj,

Silamban, and T. Sundarraj for assisting with fieldwork and Sci-Hub for providing access to the relevant literature.

Received 22 January 2021; revised accepted 12 May 2021

doi: $10.18520 / \mathrm{cs} / \mathrm{v} 121 / \mathrm{i} 2 / 294-305$ 